\title{
Use of calcium phosphate cement scaffolds for bone tissue engineering: in vitro study ${ }^{1}$
}

\author{
A utilização do cimento de fosfato de cálcio como arcabouço para engenharia de tecido ósseo: \\ estudo in vitro
}

\author{
Taís Somacal Novaes SilvaI, Bruno Tochetto Primo ${ }^{\mathrm{II}}$, Aurelício Novaes Silva Júnior ${ }^{\mathrm{III}}$, Denise Cantarelli Machado ${ }^{\mathrm{IV}}$, Christian \\ Viezzerv $^{\mathrm{V}}$, Luis Alberto Santos ${ }^{\mathrm{VI}}$ \\ ${ }^{1}$ Research performed at the Institute of Biomedical Research, Sao Lucas Hospital, Pontifical Catholic University of Rio Grande do Sul (PUCRS), \\ Brazil. Part of a thesis: Tutor, Denise Cantarelli Machado. \\ ${ }^{\mathrm{I}}$ Fellow PhD degree, Department of Oral and Maxillofacial Surgery (OMFS), School of Dentistry, PUCRS, Porto Alegre-RS, Brazil. Main author. \\ Conception, design, intellectual and scientific content of the study. \\ ${ }^{\text {II }}$ Fellow Master degree, OMFS, School of Dentistry, Lutheran University of Brazil (ULBRA), Canoas-RS, Brazil. Acquisition and interpretation \\ of data. \\ ${ }^{\text {III }} \mathrm{PhD}$, Full Professor, OMFS, School of Dentistry, ULBRA, Canoas-RS, Brazil. Responsible for conception of the study and critical revision. \\ ${ }^{\text {IV }}$ PhD, Full Professor, Department of Cellular Biology and Respiratory Diseases, School of Dentistry, PUCRS, Porto Alegre-RS, Brazil. Tutor. \\ Supervised all phases of the study and manuscript writing. \\ ${ }^{v}$ Fellow Master degree, Department of Cellular Biology and Respiratory Diseases, School of Dentistry, PUCRS, Porto Alegre-RS, Brazil. Acquisition \\ and interpretation of data. \\ ${ }^{\text {VI }} \mathrm{PhD}$, Full Professor, Department of Materials, School of Mechanical Engineering, UFRGS, Porto Alegre-RS, Brazil. Critical revision.
}

\begin{abstract}
Purpose: To evaluate the ability of macroporous tricalcium phosphate cement (CPC) scaffolds to enable the adhesion, proliferation, and differentiation of mesenchymal stem cells derived from human bone marrow. Methods: Cells from the iliac crest of an adult human donor were processed and cultured on macroporous CPC discs. Paraffin spheres sized between 100 and $250 \mu \mathrm{m}$ were used as porogens. Cells were cultured for 5, 10, and 15 days. Next, we assessed cells' behavior and morphology on the biomaterial by scanning electron microscopy. The expression levels of the BGLA and SSP1 genes and the alkaline phosphatase (ALP) activity were quantified by the quantitative real-time polymerase chain reaction technique (QT-PCR) using the fluorophore SYBR GREEN ${ }^{\circledR}$. Results: QT-PCR detected the expression of the BGLA and SSP1 genes and the ALP activity in the periods of 10 and 15 days of culture. Thus, we found out that there was cell proliferation and differentiation in osteogenic cells. Conclusion: Macroporous CPC, with pore sized between 100 and $250 \mu \mathrm{m}$ and developed using paraffin spheres, enables adhesion, proliferation, and differentiation of mesenchymal stem cells in osteogenic cells and can be used as a scaffold for bone tissue engineering.
\end{abstract}

Key words: Biocompatible Materials. Stem Cells. Bioengineering. Bone Cements.

\section{RESUMO}

Objetivo: Avaliar a capacidade de suportes tridimensionais macroporosos de cimento de fosfato de cálcio (CFC), de permitir a adesão, proliferação e diferenciação de células-tronco mesenquimais derivadas da medula óssea humana. Métodos: células obtidas da crista ilíaca de um doador humano adulto foram processadas e cultivadas sobre suportes de CFC, macroporosos, que tiveram como corpo gerador de poros, microesferas de parafina, com tamanho entre 100 e $250 \mu \mathrm{m}$. Os períodos de cultura estabelecidos foram de cinco, 10 e 15 dias. Após estes períodos, o comportamento e a morfologia das células junto ao biomaterial foram avaliados por meio de Microscopia Eletrônica de Varredura. Os níveis de expressão dos genes BGLA e SSP1 bem como a atividade da Fosfatase Alcalina (ALP) foram quantificados pela técnica de PCR em Tempo Real (QT-PCR) utilizando o fluoróforo SYBR Green ${ }^{\circledR}$. Resultados: O QT-PCR detectou a expressão dos genes $B G L A$ e $S S P 1$ e a atividade da fosfatase alcalina nos períodos de 10 e 15 dias de cultura. No período de cinco dias, não foi observada a expressão de nenhum dos genes investigados. Conclusão: O CFC, macroporoso, com tamanho de poros entre 100 e $250 \mu \mathrm{m}$, criados por meio da utilização de microesferas de parafina, permite a adesão, proliferação e diferenciação de células-tronco mesenquimais em células osteogênicas, podendo ser utilizado como arcabouço para engenharia de tecido ósseo.

Descritores: Materiais Biocompatíveis. Células-Tronco. Bioengenharia. Cimentos para ossos. 


\section{Introduction}

The strategies commonly used to treat bone defects in the maxillofacial region include autogenous bone grafts, allografts, metals and ceramics. All these alternatives have specific limitations such as restricted amount of tissue obtained with autogenous grafts, difficulty of preparing grafts with the desired shape, and risk of transferring pathogens when using synthetic implants and allograft ${ }^{1}$.

The regenerative medicine that makes use of stem cells is a fast developing field in the treatment of bone defects ${ }^{2}$. Its basic principle involves the use of an appropriate type of cell and a biocompatible and bioabsorbable scaffold (matrix, carrier) to produce a biosystem that mimics the function and structure of a specific type of tissue ${ }^{3}$.

Recently, much attention has been paid to the use of calcium phosphate cement (CPC) as a bone substitute. Such biomaterial has a composition and structure very similar to the mineral portion of the bone tissue and has been considered appropriate to develop scaffolds for bone tissue engineering ${ }^{4}$. In addition to these characteristics, CPCs are also easily handled and molded.

The main objective of this study was to assess the viability of using a CPC made of Brazilian raw material, with porosity created by paraffin spheres, as a scaffold for bone tissue engineering by analyzing the behavior of mesenchymal stem cells cultivated in osteogenic induction medium on this biomaterial.

\section{Methods \\ CPC scaffolds}

We selected 15 tricalcium phosphate cement scaffolds of $15 \mathrm{~mm}$ in diameter (Figure 1A) and around $3 \mathrm{~mm}$ in height (Figure 1B). The paraffin spheres used as porogens were responsible for the macroporous and interconnected structure of the scaffolds. Based on the fact that, according to the literature ${ }^{5,6}$, optimal pore size for bone tissue growth is above $100 \mu \mathrm{m}$, we decided to use a size range between 100 and $250 \mu \mathrm{m}$. Alpha-tricalcium phosphate cement $(\alpha-$ TPC) was synthesized in a laboratory according to the method reported by Driessens ${ }^{7}$. Scaffolds were produced by the homogenization of paraffin spheres and $\alpha$-TPC, with the later addition of the liquid phase. This phase was always added in the proportion of $1 \mathrm{ml}$ for each $1 \mathrm{~g}$ of $\alpha$-TPC. The resulting paste was poured into silicon molds and the test specimens were removed from the mold after $24 \mathrm{~h}$, then undergoing another heat treatment for paraffin removal. The characteristics of the specimens were obtained by scanning electron microscopy (SEM), which identified the morphology, distribution and size of the pores in the scaffolds.
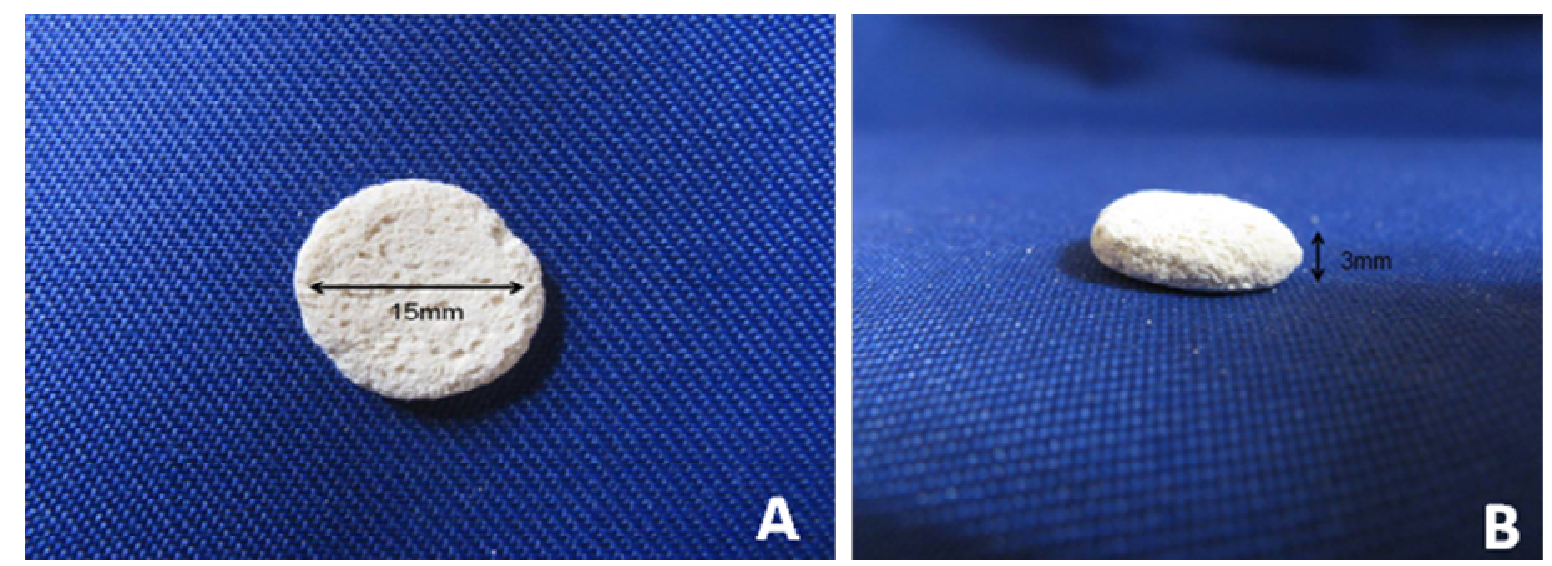

FIGURE 1 - CPC scaffolds. A) Top view: a diameter of $15 \mathrm{~mm}$. B) Lateral view: height of approximately $3 \mathrm{~mm}$.

After being autoclaved at $121^{\circ} \mathrm{C}$ for $15 \mathrm{~min}^{8}$, scaffolds were arranged on 24-well polystyrene plates $\left(\right.$ Nunclon $^{\mathrm{TM}}$ Delta Surface, Nunc Products; Denmark), with one plate for each culture period of 5, 10 and 15 days.

Each plate held five discs, with four of them being used to carry out the quantitative real-time polymerase chain reaction technique (QT-PCR), with the purpose of measuring the expression of the genes encoding osteopontin (OP), osteocalcin (OC), and alkaline phosphatase (ALP), and one gene to assess the behavior and morphology of the cells that adhered to the CPC using SEM.

\section{Human bone marrow cell culture}

Human bone marrow cells in good physiological state were obtained from a 44-year-old patient admitted to the Oral and
Maxillofacial Surgery Unit of Hospital Independência, Lutheran University of Brazil (ULBRA), for atresic maxilla reconstruction surgery using autogenous iliac crest bone graft. Purified bone marrow cells were suspended in a Dulbecco's modified Eagle medium (DMEM), supplemented with $10 \%$ bovine fetal serum, $100 \mathrm{U} / \mathrm{ml}$ penicillin, $100 \mu \mathrm{g} / \mathrm{ml}$ streptomycin, and $50 \mu \mathrm{g} / \mathrm{ml}$ gentamicin. After being suspended the cells were counted. A new culture medium was then added to adjust cell concentration. This medium was composed of $40 \mu \mathrm{g}$ of bone morphogenic protein 4 (BMP-4) per $\mathrm{ml}$ of DMEM. The suspension was added to the previously prepared 24 -well plates containing the $\mathrm{CPC}$ scaffolds in aliquots of $500 \mu \mathrm{l}$ with a density of $0.5 \times 10^{5}$ cells per milliliter, being counted in a hemocytometer. Finally, cultures were incubated and kept in a humidified oven at $37^{\circ} \mathrm{C}$ containing $5 \%$ of $\mathrm{CO}_{2}$. 
Analysis of the expression of the bgla, ssp1 and alkaline phosphatase genes

The expression levels of the BGLA and SSP1 genes, which encode OC and OP, respectively, and the ALP activity were quantified by the QT-PCR technique using fluorophore SYBR GREEN $^{\circledR}$. The QT-PCR technique used in the present study was based on the amplification of the cDNA with gene-specific primer oligonucleotides and detection using a laser beam able to capture the fluorescence emitted by the fluorophore SYBR Green ${ }^{\circledR}$ at each synthesis cycle. This process made it possible to quantify the levels of the sequences complementary to mRNA for those genes present in the specimens analyzed.

\section{Scanning electron microscopy}

After each culture period, the discs were assessed by SEM to analyze the behavior of the cells in contact with the biomaterial surface. The scanning electron microscope used in our study was a PHILIPS ${ }^{\circledR}$ device, model XL30. A thin layer of gold was sputtered on the specimens analyzed.

This research project was approved by the Scientific and Ethics Committee of the School of Dentistry of PUCRS and by the Research Ethics Committee of PUCRS. This study is in accordance with items III.3.i and III.3.t of the Brazilian Guidelines and Norms for Research involving Humans.

\section{Results}

\section{Characterization of the specimens}

The SEM images showed the spherical shape of the pores and their interconnectivity (Figure 2). The amount of spheres added is linked to the formation of a thin layer of cement between the spheres, enabling them to have contact with one another and, thus, after paraffin removal, promoting the establishment of interconnections between the pores generated by the paraffin spheres. The size of the pores we found is the same as the size of the paraffin spheres used, ranging from 100 and $250 \mu \mathrm{m}$.

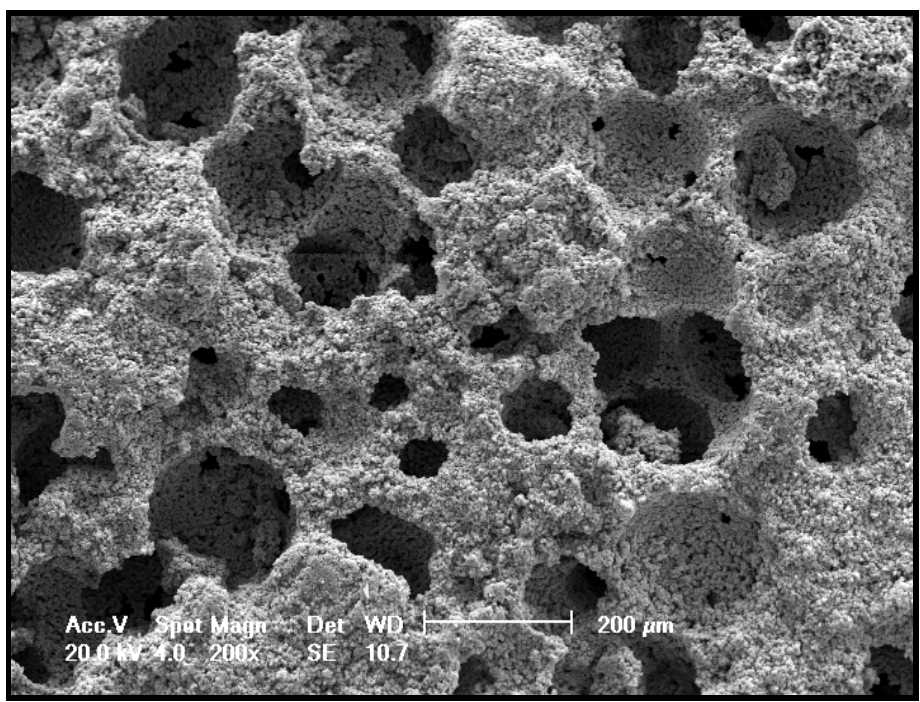

FIGURE 2 - Scanning electron micrography of the macroporous CPC surface. Magnification of 200x.

\section{Scanning electron microscopy}

On the fifth day of culture, we found a small number of elongated and fusiform cells (Figure 3 ).

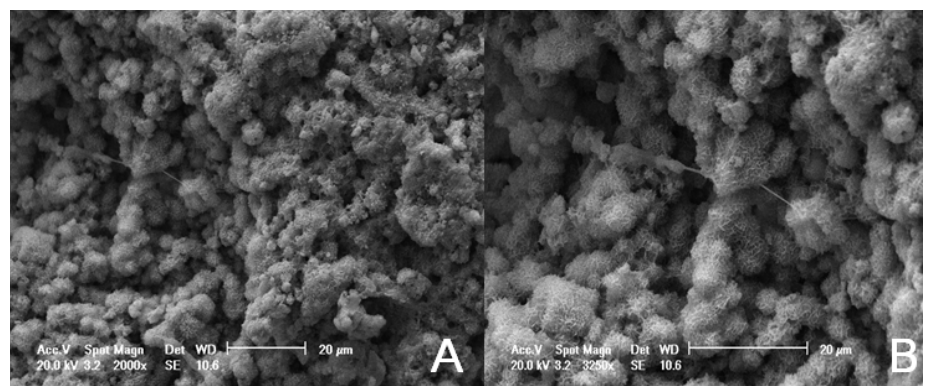

FIGURE 3 - Scanning electron micrography of cells adhered to the macroporous CPC surface on the fifth day of culture. A) Magnification of 2000x, B) Magnification of 3250x.

On the tenth day of the experiment, we could observe the deposition of the extracellular matrix on the biomaterial. There were cell elongations inside the pores (Figure 4). Cells began to have a cuboidal shape.

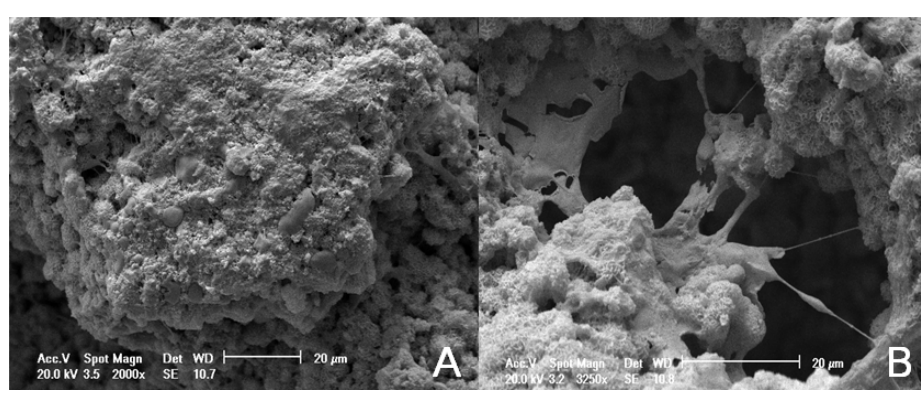

FIGURE 4 - Scanning electron micrography of cells adhered on the macroporous CPC surface on the tenth day of culture. A) Magnification of 2000x, B) Magnification of 3250x.

On the 15th day of culture, we could observe cuboidal cells (Figure 5A), compatible with the morphology of osteogenic cells. There were connections between the cells (Figure 5B). We also found that the cells and their elongations had migrated to the inner portion of the pores.

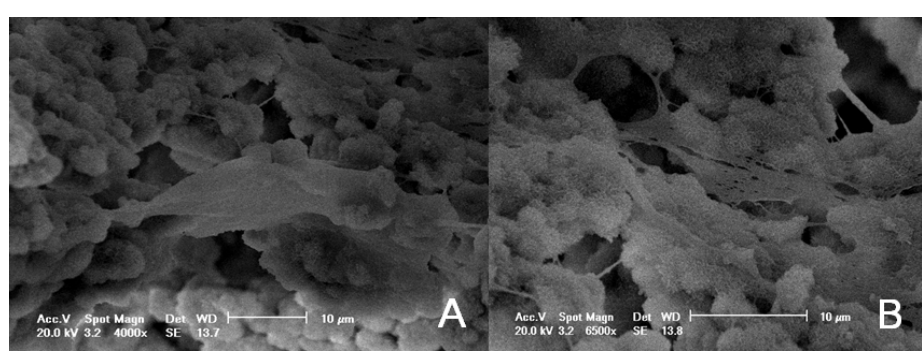

FIGURE 5 - Scanning electron micrography of the cells adhered on the macroporous CPC surface after 15 days of culture. A) Magnification of 4000x, B) Magnification of 6500x. 
op, oc and alp

Real-time PCR for expression of the genes encoding

The expression of the BGLA and SSP1 genes responsible for encoding $\mathrm{OC}$ and $\mathrm{OP}$, respectively, and the
ALP activity were detected by the QT-PCR technique.

The value of the threshold cycle $\left(\mathrm{C}_{\mathrm{T}}\right)$ was determined by the thermal cycler to measure the expression. We calculated the mean and standard deviation of the $\mathrm{C}_{\mathrm{T}}$ values based on duplicate analysis (Table 1).

TABLE $1-C_{\mathrm{T}}$ values for the expression of the $\beta$-actin, BGLA, SSP1, and ALP genes at different periods of culture

\begin{tabular}{ccccc}
\hline & $\boldsymbol{\beta}$-actin & ALP & $\begin{array}{c}\text { SSP1 } \\
\text { (Osteopontin) }\end{array}$ & $\begin{array}{c}\text { BGLA } \\
\text { (Osteocalcin) }\end{array}$ \\
\hline 5 days & 0 & 0 & 0 & 0 \\
$\mathbf{1 0}$ days & $53 \pm 0.14$ & $40.95 \pm 0.21$ & $38.8 \pm 0.14$ & $35.45 \pm 0.07$ \\
$\mathbf{1 5}$ days & $42.6 \pm 0.14$ & $34.35 \pm 0.35$ & 37.5 & $34.65 \pm 0.07$ \\
\hline
\end{tabular}

Data are given as means $\pm \mathrm{SD}$

$\mathrm{C}_{\mathrm{T}}$ values represent the cycle in which the gene started to be expressed. The lower the $\mathrm{C}_{\mathrm{T}}$ value, the earlier the gene expression was detected.

The levels of the relative expression of each gene were normalized with the expression of $\beta$-actin in the relation $\left(\mathrm{C}_{\mathrm{T}(\mathrm{OP} / \mathrm{OC} / \mathrm{ALP}} / \mathrm{C}_{\mathrm{T}(\beta \text {-actin })}\right)$, where we found the values described next (Table 2).

TABLE 2 - Normalized CT values of the ALP, SSP1, and BGLA genes' expression

$\begin{array}{lcc}\text { ALP } & \text { SSP1 } & \text { BGLA } \\ & \text { (Osteopontin) } & \text { (Osteocalcin) }\end{array}$

\begin{tabular}{llll}
$\mathbf{5}$ days & - & - & - \\
$\mathbf{1 0}$ days & 0.77 & 0.73 & 0.66 \\
$\mathbf{1 5}$ days & 0.80 & 0.88 & 0.81 \\
\hline
\end{tabular}

After normalization of the $\mathrm{C}_{\mathrm{T}}$ values, we could compare the relative expression of the genes during the periods studied and we found, as shown in the previous table, that in the 15-day period there was higher expression of all the genes investigated.

\section{Discussion}

Several materials have been investigated as potential scaffolds for bone tissue engineering. Each one of them has advantages and limitations. In the present study, we decided to investigate CPC made of Brazilian raw material based on its low cost in comparison with the imported cements available in the market and because the national material showed biocompatibility and easiness of handling similar to those of imported cements.

One of the characteristics required by bone tissue engineering for scaffolds is that they must have a porous and interconnected structure, enabling the migration and distribution of cells ${ }^{9}$. With the purpose of achieving this characteristic, we decided to use paraffin spheres as porogens in the scaffolds. Paraffin was chosen because it is an organic material with a low melting point, which made it possible to control the distribution and size of the pores, thus producing a macroporous and interconnected scaffold.

Tissue engineering involves the association of an osteoconductive matrix (CPC in the present study), osteoprogenitor cells, and osteoinductive growth factors. Our choice for mesenchymal stem cells derived from human bone marrow is based on their potential of expansion and differentiation in specific strains, as well as their autogenous origin, which make them good candidates for use in tissue engineering and regenerative therapies. As they have advantages in comparison with other types of cells, mesenchymal stem cells have been widely used in bone tissue engineering ${ }^{3,4,9}$.

No consensus has been reached in the literature regarding the pore size that best promotes osteoconduction. It has been established that bone growth occurs when the pore is large enough to house the cells and the blood flow system. A pore size larger than $100 \mu \mathrm{m}$ and smaller than $400 \mu \mathrm{m}$ is usually considered optimal for osteoconduction ${ }^{10}$; however, there are conflicting scientific reports demonstrating that there can occur bone growth in pores smaller than $100 \mu \mathrm{m}$ and larger than $500 \mu \mathrm{m}^{11}$. In the present study, we decided to use the range $100-250 \mu \mathrm{m}$ because such porosity enables cell growth, but does not have a significant influence on the mechanical resistance of the biomaterial, as there is a close relationship between porosity and the amount and size of pores ${ }^{12}$.

Based on the SEM images obtained in the present study, we could confirm that there was cell proliferation on the CPC scaffold. We were also able to detect differentiation of osteogenic cells. Such differentiation was made evident by their cuboidal shape compatible with the shape of osteogenic cells, which was acquired close to the 15th day of culture. The QT-PCR technique corroborated these findings with the detection of the expression of the genes investigated in the 10- and 15-day period of culture.

On the 15th day of culture, we used QT-PCR to detect the expression of the BGLA and SSP1 genes responsible for 
encoding OC and OP, respectively. We also detected ALP activity, and the results showed an earlier detection of the expression of these genes throughout the experiment periods. Such data allow us to conclude that there was cell proliferation and osteogenic differentiation during these periods, since these proteins are considered osteoblast markers because they are exclusively expressed by preosteogenic cells and mature osteoblasts, except for OP, which is detectable in precursor cells at early stages of differentiation $^{8,13}$

Several authors have drawn attention to the need of good mechanical properties in scaffolds intended to be used in bone tissue engineering ${ }^{14}$. However, we tend to agree with LogeartAvramoglou, ${ }^{9,11}$ when they state that such requirements are not necessary because the main function of a scaffold is to support bone growth instead of supporting mechanical forces. The scaffolds investigated in the present study were minimally resistant, which was sufficient for them to be handled, as this resistance would increase with the proliferation of osteoblasts while generating bone tissue.

$\mathrm{CPC}$ has a great potential for being used in bone tissue engineering and its association with polymeric materials is a quite promising field for further investigations aimed at combining the advantages of both materials.

\section{Conclusion}

Based on the findings of the present study, we conclude that CPC scaffolds with macroporosity generated by paraffin spheres have interconnected pores and pore sizes compatible with the size of the spheres used, which was between 100 and $250 \mu \mathrm{m}$. These scaffolds enabled adhesion, proliferation, and differentiation of the mesenchymal stem cells in osteogenic cells and, therefore, can be used as scaffolds for tissue engineering.

\section{References}

1. Turhani D, Watzinger E, Weissenböck M, Cvikl B, Thurnher D, Wittwer G, Yerit K, Ewers R. Analysis of cell-seeded 3-dimensional bone constructs manufactured in vitro with hydroxyapatite granules obtained from red algae. J Oral Maxillofac Surg. 2005;63(5):673-81.
2. Kasten P, Beyen I, Niemeyer P, Luginbühl R, Bohner M, Richter W. Porosity and pore size of $\beta$-tricalcium phosphate scaffold can influence protein production and osteogenic differentiation of human mesenchymal stem cells: an in vitro and in vivo study. Acta Biomater. 2008;4(6):1904-15.

3. Li WJ, Tuli R, Huang X, Laquerriere P, Tuan RS. Multilineage differentiation of human mesenchymal stem cells in a three-dimensional nanofibrous scaffold. Biomaterials. 2005;26(25):5158-66.

4. Guo H, Su J, Wei J, Kong H, Liu C. Biocompatibility and osteogenicity of degradable Ca-deficient hydroxyapatite scaffolds from calcium phosphate cement for bone tissue engineering. Acta Biomater. 2009;5(1):268-78.

5. Gauthier O, Bouler JM, Aguado E, Pilet P, Daculsi G. Macroporous biphasic calcium phosphate ceramics: influence of macropore diameter and macroporosity percentage on bone ingrowth. Biomaterials. 1998;19(1-3):133-9.

6. Chang BS, Lee CK, Hong KS, Youn HJ, Ryu HS, Chung SS, Park KW. Osteoconduction at porous hydroxyapatite with various pore configurations. Biomaterials. 2000;21(12):1291-8.

7. Fernández E, Gil FJ, Ginebra MP, Driessens FC, Planell JA, Best SM. Production and characterization of new calcium phosphate bone cements in the CaHPO4-alpha-Ca3(PO4)2 system: $\mathrm{pH}$, workability and setting times. J Mater Sci Mater Med. 1999;10(4):223-30.

8. Ozawa S, Kasugai S. Evaluation of implant materials (hydroxyapatite, glass-ceramics, titanium) in rat bone marrow stromal cell culture. Biomaterials. 1996;17(1):23-9.

9. Logeart-Avramoglou D, Anagnostou F, Bizios R, Petite H. Engineering bone: challenges and obstacles. J Cell Mol Med. 2005;9(1):72-84.

10. Boyan BD, Hummert TW, Dean DD, Schwartz Z. Role of materials surfaces in regulating bone and cartilage cell response. Biomaterials. 1996;17(2):137-46.

11. Cyster LA, Grant DM, Howdle SM, Rose FR, Irvine DJ, Freeman D, Scotchford CA, Shakesheff KM. The influence of dispersant concentration on the pore morphology of hydroxyapatite ceramics for bone tissue engineering. Biomaterials. 2005;26(7):697-702.

12. Chouteau J, Bignon A, Chavassieux P, Chevalier J, Melin M, Fantozzi G, Boivin G, Hartmann D, Carret JP. Cellular culture of osteoblasts and fibroblasts on macroporous calcium-phosphate bone substitutes. Rev Chir Orthop Reparatrice Appar Mot. 2003;89(1):44-52.

13. Aubin JE. Advances in osteoblast lineage. Biochem Cell Biol. 1998;76(6):899-910.

14. Kim K, Yeatts A, Dean D, Fisher JP. Stereolithographic bone scaffold design parameters: osteogenic differentiation and signal expression. Tissue Eng Part B Rev. 2010 May 26. [Epub ahead of print]

\section{Correspondence:}

Taís Somacal Novaes Silva

Av. Visconde do Herval, 915/604

91450-151 Porto Alegre - RS Brasil

Phone/Fax: (55 51)3225-2521

tais.somacal@hotmail.com

Received: July 06, 2010

Review: September 14, 2010 Accepted: October 19, 2010 